\begin{tabular}{c} 
Volume and Issues Obtainable at Center for Sustainability Research and Consultancy \\
Sustainable Business and Society in Emerging Economies \\
ISSN: 2708-2504 ISSN (E) 2708-2172 \\
Volume 1: No. 1, June 2019 \\
CSRᄃ \\
Journal homepage: www.publishing.globalcsrc.org/sbsee \\
\hline
\end{tabular}

\title{
Toward Socially Sustainable Tourism: the Impact of Tourism on SMEs and Livelihood Development at Tourism Destinations in Bahawalpur Pakistan
}

\author{
${ }^{1}$ Rahim Mukhtar
}

${ }^{1}$ The Islamia University of Bahawalpur Pakistan: Rahim.mukhtar2040@ gmail.com

\begin{tabular}{l}
\multicolumn{1}{c}{ ARTICLE DETAILS } \\
\hline History \\
Revised format: May 2019 \\
Available Online: June 2019 \\
Keywords \\
Sustainable Tourism, Tourism \\
Related SMEs, Community \\
Development, Livelihood \\
Development
\end{tabular}

JEL Classification:

Q01, R11, R19

\section{ABSTRACT}

Financial The purpose of this study is to analyse the impact of tourism on SMEs and livelihood development at local area (tourism destination). The idea behind preparing this thesis is to study and relate to this particular scenario which is green tourism within Pakistan. Sustainable tourism should provide a better vacation experience, and for local residents to seek better tourism business opportunities. Higher quality of life is achieved through societal and cost-effective benefits. The information is based on the response of the individuals surveyed. It also includes the current and past data of tourism. To accomplish the purpose of the research, the data was acquired from the tourism related SMEs owners and managers with a sample of 250, chosen randomly of South Punjab, Pakistan The scope of the comprehensive thesis is limited to the responses of the individuals. This thesis is a modest attempt towards the conclusion that tourism research is very important because in previous years there has been a significant increase in tourism, which helps in boosting the economy. This paper is about the sustainability of tourism in which the small scale tourism related SMEs, personal improvement of SMEs owner manager, and livelihood development of local communities are the independent sub variable and the dependent variable livelihood development in the local area (tourism destination).Data analysis was conducted using a reliability test, Multicollinearity, correlation, regression, demographic and normality test. Finally, the results of this intended study revealed that there is a moderate significant of local area (tourism destination) with respect to small scale tourism related SMEs and livelihood development of local community, not significant with respect to personal improvement of SMEs owner manager. Government should try hard for the promotion and revival of tourism to increase the community development and SMEs development. Furthermore, this study recommends future researchers to focus on internal and as well as external factors of tourism and its related SMEs in Pakistan.

\section{OPEN ACCESS}


Corresponding author's email address: mukhtar2040@gmail.com

Recommended citation: Mukhtar, R., (2019). Does Toward Socially Sustainable Tourism: the Impact of Tourism on SMEs and Livelihood Development at Tourism Destinations in Bahawalpur Pakistan. Sustainable Business and Society in Emerging Economies, 1(1), 43-54

DOI: $10.26710 /$ sbsee.v1i1.1005

\section{Introduction}

The idea of sustainable tourism has established noticeable consideration in 2002 by intellectuals of the travel field Spensley et al., who have said that responsible tourism should provide a better vacation experience, and for local residents to seek better tourism business opportunities. Higher quality of life is achieved through societal and cost-effective benefits. The use of resources in a tourist destination without harming nature is also of utmost importance. Having established that it is necessary for the sector to expand their business in order to create more opportunities, this idea has become mainstream in tourism literature. However, most studies were conducted in the context of tourists or service providers. In 1998 SMEDA came into being, with the main motto of this organisation being to give ideas to different people. It also solved the financial issue of SMEs sector. To lend a helping hand in creating jobs and value addition is their primary goal. They are also conducting different studies for the betterment of the business, and if there is a new addition in the international market, they promote it in the Pakistani market. They are trying their best to give support to young entrepreneurs. Here to quote Eva Zubeck, a famous travel vloger, "let me give you a few arguments as to why I think so, starting with the mountains of Pakistan. One of the greatest assets that nature has bestowed on this country. Beyond the current resort of Malam Jabba and Naltar. Why can't ski resort dot the peak of mountains? Beyond that, hiking at the beautiful landscapes of Skardu, Hunza and Swat. Why can't Pakistan become the next Bhutan or Nepal with mountaineering and maintain trekking infrastructures that rival those of neighbouring countries with 8 out of the world's 20 tallest mountains. This should be the epicentre of the world's trekking, adventure and mountain tourism. And just look at the mountains of the south, the hingol national park of Baluchistan. Why can't this become the next Grand Canyon? Just imagine tourists trekking, hiking and camping among the beautiful nature made structures. How can we forget the entire coast of the Arabian Sea, with the right attitude has become one of the world's prime beach destinations for all seasons? Imagine five star resort, private islands and beach shacks lining the beautiful coastline." Next is culture and the arts; Sindh, Lahore, Bahawalpur, Multan etc., have so much to offer. The craftsmanship, artistry and handicrafts I have seen are unlike anywhere else in the world. This could grow to be Pakistan's prime export. Imagine hundreds of thousands of tourists bringing bits of Pakistan back home with them, to share with their communities. There is also the concept of religious tourism: Pakistan has such an incredible Islamic heritage, and everyone knows of the Sufi trail of Sindh, which can appeal not only to Muslim tourists, but anyone interested in history and culture. Pakistan also happens to be the birthplace of Sikhism, and the travels of Guru Nanak. It is also home to some of the most important Hindu sites in the world, as well as Buddhist stupas, and the remains of a rich Buddhist heritage. Why don't more people around the world know that Pakistan is where one of the world's oldest civilizations, the Indus civilization was found? What exactly is preventing Pakistan from becoming the world's top destination for history buffs? Furthermore, there is the food of Pakistan. Pakistan has such a rich culture of food and cuisines, and the diversity from province to province is just astonishing. Why can't small places become some of the world's top culinary hubs for foodie tourism? Such is the state of Pakistan, and it is going to take much time, effort, dedication, and investment to turn our vision into reality. But everyone knows that the gifts that Pakistan has been blessed with are endless. This is how tourists see the future of tourism in Pakistan". The city is located near the traditional Derawar fort within the Cholistan Desert near the Indian Republic Border and is located in Pakistan's Red Sohanra National Park. Bahawalpur was once the capital of the former state of Bahawalpur under the Nawab. There are many tourism places because Bahawalpur is considered as a heritage city. Places like Bahawalpur Museum, Dubai Palace, Central Library, Jami Masjid al Sadiq, Noor palace, Darbar palace, SS World, the Zoo, Derawar Fort, National Park, Bahawalpur Gates, Gulzar Palace, Quaid-e-Azam Solar Park, Abbasia Mosque and Sadiq Public School, SD School and Canner Peer ka mela are main tourist attractions of Bahawalpur. Tourism contributes $\$ 8.8$ 
trillion and 319 million employments to the world economy in 2018, which is almost $3.9 \%$ more than previous years' data given by world travel and tourism council. However, this proves the command of Travel \& Tourism as an instrument for administrations to produce success while generating jobs which mostly support youth, women, and other, often help groups of the public. World Travel and tourism Council say that tourism contribute approximately $\$ 19.4$ billion in 2018 which is about 6.9 percent of the total GDP. WTTC expecting \$36.2billion in coming 10 years. The people and businesspersons should participate in developing and start their minor industries to sell fruits, teas, handiwork sweets, wood carving, pottery and accommodation etc. people now have finance with tourism awareness started their hotel services, elephant riding, travel agency, souvenir, nature tracking, and handicraft shops etc. Some are financed in foreign partnerships that are more aware and network in overseas connection. Tourism and travel contain that businesses, food, and wholesale trade housing services, drink services, carriage services and cultural, sports and entertaining services. It is projected that approximately 90 per cent of the business in tourism connected industries are SMEs (European Union (EU), 2015). Formal SMEs generate almost $60 \%$ of employment and almost $40 \%$ of total (GDP) in developing economies. These numbers are considerably higher when informal SMEs are included. According to World Bank report, 600 million jobs are required in coming 15 year to control unemployment. In developing markets, most formal jobs are produced by SMEs, it also generate 4 out of 5 new post. According to the Small \& Medium Enterprise Development Authority (SMEDA) SMEs create almost 90 percent of all firms in Pakistan, and give jobs to 80 percent of non-agricultural labour force which is almost $40 \%$ of the total GDP. Yet, in developing countries, while tourism can carry economic benefits to a host country, it also get thoughtful long-term difficulties we have to be careful about these problems. We need proper planning and power to tackle all the concern .Most of the research study on the effect of tourism or SMEs or socio economic impact of tourism, but my study is a combination of both.

\section{Gaps of the study \\ Theoretical Gaps}

Many Researchers have been based on different theories. The researcher used theories to determine socio economic impact of tourism. In past research concentrate concentrated on assessment of the impacts of the going on progression, close by systems and to see the tempers and impression of close by systems towards the movement business improvement in their neighbourhoods. This examination will centres around Small scale the travel industry related SMEs, individual improvement of SMES and occupation of nearby network. The travel business has converted into an important part in both created and creating nations, including Pakistan. Tolerating positive aspect of interest of the travel, much research has been completed on SMEs in the travel industry. Be that as it may, direct effect of the travel industry on business execution and improvement in neighbourhood absolutely unnoticed.

\section{Contextual Gaps}

This research study specifically focuses on the context of south Punjab in Pakistan. One of the developing countries districts that has many tourist places. There is a significant growth of tourism is south Punjab Yet, there is no research study to inspect the impression of tourist on SMEs and local development of south Punjab, mostly along the profile of tourism related industries. This investigation will discover execution of the travel industry on the individual improvement of business visionaries. Impact of cityhood of local community and perception of overall livelihood development of local area. This study tends to fill this gap by finding out what is the condition of entrepreneurs' who are currently working in the field of tourism related business.

\section{Scope of Research Study}

This examination study has a very broad scope in future for the people and specially Government, economists, NGOs', policy makers, SMEs managers and Owners Managers of Pakistan because tourism is growing day by day in Pakistan. The market of tourism is almost $\$ 19.8$ and increasing very fast. The research study was conducted within the context of South Punjab (Pakistan), SMEs located in South Punjab (Pakistan). The economy of Pakistan is considered important for SMEs. This study is helpful for 
local community to find out the condition of Small-Medium enterprises for developing their area. This examination finding the figures that would set up to improve aptitudes in addition to creative plays out that may build up the lives of individuals and business people specifically. This investigation will ready to reveal potential outcomes that can address the opening of the projects in the travel industry and business enterprise that upgrade work in South Punjab.

\section{Research Objectives}

RO1: To analyse the impact of tourism on tourism related SMEs and Livelihood development in the local area.

RO2: To analyse the impact of tourism on Personal improvement of SMEs owner manager and livelihood development in the local area.

RO3: To analyse the impact of tourism on Livelihood development of locals and livelihood development in local area.

\section{Literature review}

\subsection{Conceptual framework}

From the sustainable tourism model my sudsy will base on only two dimensions social and economic, study based on SMEs and local community development.

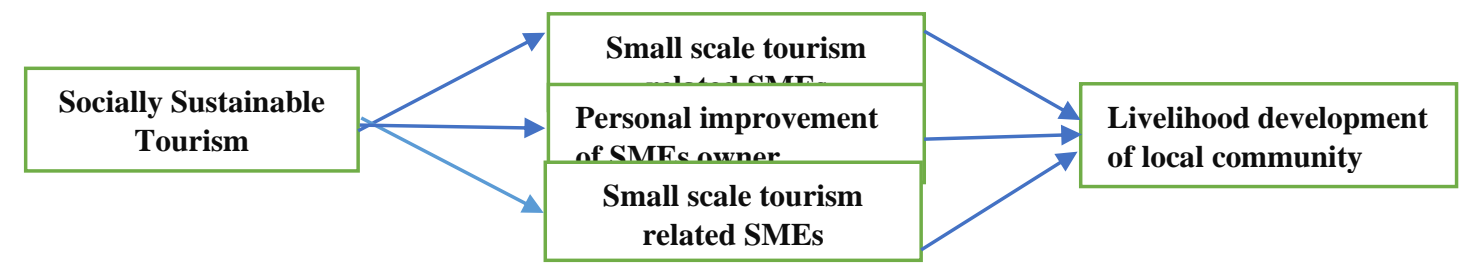

\subsection{Small scale tourism related SMEs}

(Othman \& Rosli, 2011)The difference is that tourism create on entrepreneurship. It create entrepreneurial development and performance of business is sighted is the literature. Tourism creates opportunities for small entrepreneurs in various tourism business activities because of low initial cost entry is quite easy .It also creates good opportunities for local agricultural, construction business, Manufacturing firms and business related to services. The most important accommodation, food chain, sport facilities retails, tourist guides are needed in tourist place. It also provides a clear indication that efforts by governments to promote the tourism industry will have a positive impact on the performance of small tourism businesses. Researcher found in this study that foreign tourists have become the largest source of African business. young (1973) makes reference to a contextual investigation of the Caribbean island of St. Lucia, where the travel industry shows up bringing about a trip of wages from the nearby banana industry, which is the principle wellspring of outside salary. Those who are left on the earth cannot cope with the labour requirements of the banana crop, which in turn reduces productivity and income. As a result of tourism, food imports have increased tremendously and at the same time there has been tremendous pressure on the balance of payments. If such a study is undertaken, a better local or foreign policy can be devised. Better policy can be devised to attract tourists or to develop the tourism sector in the future. Based on the researchers' observations, it was found that owners have little information in business management because many of them do not even have accurate records of business transactions, thus allowing for more complex accounting systems. In this way, a research about this area will help small businesses improve their performance.

\subsection{Personal Improvement of SMEs Owner Manager}

(Gnanapala \& Sandaruwani, 2016)International Journal of Economics and Business Administration stated that, the effects of tourism on locals and views and awareness of local people towards tourism progress in their region. The learning shown that this industry is increasing day by day and local are satisfy with the progress, developing project and tourism related activities. The study was directed in a less technologically advanced and waterless zone, the area that is badly affected by climate change and 
poverty. The people of this area mainly dependent on agriculture and their income is not fixed and it is unstable. As an effect of that, the people of the area is interested to be the part of tourism business and opening their personal minor scale organizations or give physical work to the development of the travel industry. Many tourism related improvement activities are going on that areas and furthermore the structure administrations of the territory are blasting alongside those advances. The administration specialists need to have an appropriate discourse with local people for the best possible contribution for the travel industry improvement exercises likewise attempt to engage local people so they would ready to get the benefits of the travel industry advancement as a designers and supervisors of the travel industry in the district. Further, it is important to give financial and moral support to local for getting benefits of tourism. The fully participation of locals will help economical, socio-cultural and environmental sustainable tourism business. It is recommended to made small scale tourism project through community involvement along with the government checking. Yet, it is required to grow a suitable planning to attract community participation.so they should have to form community organization. The government and other accountable organizations should follow all this and try their best to made development and empowerment of locals. The standard and big scale development projects are essential for local public. There should be joint venture public and private for development projects. Government must manage all these things for the betterment of industry sector and the benefits of that city people.

\subsection{Livelihood Development of local Community}

(Sutawa, 2012) state in is study Community power is a main key. If local people standard of living increase then area will also develop because of tourism. Village tourism developments one of the important areas which we have to focus on. Village tourism is a u age thing which increase the standard of rural people, and gives power to that people i.e. Improvement on tourism information for public and tourist persons and give knowledge about sustainable tourism, its mean how we develop tourism area without harming the environment. By empowering the local community can give fully independence to every people of the society that knowledge will help individual to find out how to use our resources and implement different things improve their prosperity. Empowerment is completed step by step with the correct perceptions and interpretations so as to avoid wrong empowerment that is not supporting sustainable empowerment principles. Condition well-disposed the travel industry improvement is worry of all partners. All issues on the travel industry advancement that make harming impact must be constrained by every on edge partner, for example network, government, NGO, Local individuals etc. would stop or circumvent ruin environment. By contribution of all stakeholders tourism development are going to be easy to achieve.

\subsection{Livelihood Development in Local Area (Tourism Destination)}

(Jaafar, Rasoolimanesh, Mohd Bakri, \& Rasoolimanesh, 2015) discusses the involvement of local communities in the development of rural tourism and the importance of rural development for tourism. This study is conducted in Malaysia kinabalu national park which is situated in the centre. Kinabalu Park was awarded world heritage site by UNESCO for its value and is ironic diversity. Due to its natural attraction, biodiversity and local community researcher get attracted toward it. This study is about the local idea toward development in neighbouring area. This data collected from mountain area as well local community people. Most of the people from the age of 21-30 started their own tourism related business. Due to the lack of education in local people, it's an ideal business for resident. Most of the young people involved in tourism industry from pass 1 to 10 year. For past 13 year there is a very dramatic change in the perception and idea of tourism industry in the mind of resident. There is a significant increase in selfemployment and farming business which rise the salary of people. According to Macdonald \& Jolliffen research paper food and beverage, Accommodation and handicraft industries are to most common sector that support in the development. There is improvement in local product due to increase in demand because of tourism development. Most of the responses were positive about tourism development because they have given chance to participate in that developing activities.. It also concluded that tourism will not promise a magical increase in development and extra source of generating income. But it is important for local area residents because it is beneficial in Eco. Social development of household income. Advantages 
to country occupants, both in financial and social terms, become negligible where there is an absence of nearby association in the travel industry improvement, or where local people can't or kept from reacting to the work openings emerging through the travel industry.

\subsection{Relationship Between the IV and DV}

(Ranasinghe, 2014)stated the relationship between variables say that most of the young and middle age entrepreneurs are hardworking and doing their work in a good way, they are capable of running their business. Females are also doing good and going neck to neck with men. They are greater risk taker than males as per the findings. Most of them already have their own families and that's give them motivation to start their business for their families. Business is gives good earning to them now it's possible for them to provide better life to family and give hope for a brighter future. Religion is most important factor that is fully related to the respondent perception toward business however some have believed hard work is worship, if we want to do some we have to pay for that. Payment is not all about money it's about your dedication, honesty and hard work. If we did all this things it help us to succeed in life and business. Now, education very greater factor in creating awareness of business. Most of them got the standard instructional accomplishment they might obtain under the conditions and upraised their chance of forming a business in the tourism section. Others who have not been able to get the chance of an honest education went into line of work faculties and offered into business just to take care of their elementary wants and provide their kids good schooling. Some of the peoples have been in business field for the many years' but are quiet struggling in their lives and others who are just started or at the beginning of their project are apparently more popular than the ones who have been in the industry longer than they have been. The impact of touristy and entrepreneurship is increasing because every establish industry is trying to develop a tourism related business. More and more and businesses are coming in that area so there is a healthy completion between people. This help locals to expend there shops or what kind of business they have. It's difficult for someone to establish their business without government assistants. Additionally, entrepreneurs have to hire workers in their business for help so it produce jobs which increase the living style of locals, Labours get jobs and earn money for better future . Government assist them in their entrepreneurial activities and observes through the conduct of extra exercise for them. Government also helping in the promotion of their product in different tourist places and cities. On the impact of tourism and entrepreneurship on the personal improvement of the entrepreneur, people are now have an opportunity to interact with many customers for building new good relationship and business relationship business. Due to government different teachings, skill development programmes and coaching programmes there is good change in people's decision making, Skills, responsibility and attitude toward. They know where to invest, how to get profit and what decision we have to take. They also manage their time for families. They do all the swot analysis before expansion. They attend different coaching programmes, conferences and workshops to lift themselves and their business management. On the impact of cityhood to tourism in Dam bulla City, this city has many tourism place. Srilanka is earning more from tourism and tourism related thing. After becoming city there is very sound increase in tourists. There are some negative effects also just like change in climate due to heavy development. In that city there are many tourist and entertaining places to visit. Development in that area also improve the facilities for tourists and make their trip entertaining and comfortable and pleasant. Researchers find that we should encourage investors to invest in different areas related to tourism sectors. There is an issue of transport in that area, so investor should invest in transport sector. Rent a car is a very popular or new age business. It will solve the problems and inconvenience of tourists. Government started different English speaking courses for the convenience of local community, because sometimes it's difficult for locals to understand foreigner language. English is an international language and medium of connection. There is also and need of business of lodging and food services. Following study will help in changing the perception of people toward tourism and tourism related business.(Mathew \& Sreejesh, 2017)investigation was an effort to build up an apparent economical goal the board model for traveller goals with the aim of improving the quality of life of the community. The finding of this study is all about local community consist of these dimensions, like community development, empowerment, skills and awareness. All these measurements imitate responsible tourism observation of the local people toward sustainable tourism of 
local community and individual. There are four sub aspects of destination sustainability such as environmental, economic, social and cultural. This examination was completed to discover the connection between capable the travel industry and goal manageability by view of nearby network as seen by the neighbourhood system. It was discovered that individual's observations about great the travel industry has a noteworthy impact on manageability and cordial demeanour toward the travel industry goal. The role of maintain sustainable destination is to increase in the livelihood. Engagement and environmental sustainability. That all things lead toward a sustainable management of a destination. While that destination try to maintain an equality between sustainability and improvement, if there is a responsible tourism there will be a sustainable development because they both linked with each other. All this discussion will helpful for the improvement of community life and awareness of resident to tourism improvement.

H1: There is significant association between tourism on tourism related SMEs and Livelihood development in local area (Tourism destination).

$\mathrm{H} 2$ : There is a significant association between the impact of tourism on Personal improvement of SMEs owner manager and Livelihood development in local area (Tourism destination).

H3: There is significant association impact of tourism on Livelihood development of locals and 1 Livelihood development in local area (Tourism destination).

\section{Research Methodology}

\subsection{Research Design}

In this research study, Causal research design is being adopted to find out the SMEs' improvement, livelihood development and local community development. It is the study based on cause and effect of relationships among variables. Previous research study also adopts the same pattern of research design.

\subsection{Research Analysis}

In previous research study many researchers used different models to test SMEs' improvement, livelihood development and local community development. In this research, SPSS was one of the best statistical tools applied for the analysis stage.

\subsection{Sample Size and Population}

The sample size of this research study to consideration of SMEs' located in South Punjab (Bahawalpur city), where the research is conducted. In this research study there are 250 respondents and the data is collected from different SMEs', which is located in South Punjab (Bahawalpur City).

$\mathrm{N}=(\mathrm{Zs} / \mathrm{e}) 2$ Where

$\mathrm{N}=$ Sample Size

As we are using a 5 point rating scale so standard deviation is calculated as follows:

Standard deviation= Maximum Rate - Minimum Rate $/ 6$

$=5-1 / 6=0.67$

$\mathrm{e}=$ Tolerable error. That will be determined by the investigator. For this research we presumed 0.1

Tolerate error

Putting all this in equation we get sample size 250

\section{Data Analysis and Interpretation}

In this research study data analysis and interpretation method through Ms Word software will be used.

\subsection{Sampling Framework}


As title suggests the study was conducted in Bahawalpur City. So the sampling framework is the SMEs of Bahawalpur.

\subsection{Sampling technique}

Non-probability sampling was selected as sampling Methods.

In this research study Simple Random sampling is being adopted for data collection and previous research study follow the same pattern.

\subsection{Data Collection Tools}

Questionnaires were used as a Data construction tool.

\subsection{Survey Method}

Direct Questionnaire Survey Method.

\subsection{Result and Discussion}

\subsubsection{Correlation}

\begin{tabular}{|c|c|c|c|c|c|}
\hline & & SM_avg & PI_avg & LD_avg & DD_avg \\
\hline \multirow{3}{*}{$\begin{array}{l}\text { Small } \\
\text { scale } \\
\text { tourism } \\
\text { related } \\
\text { SMEs }\end{array}$} & Pearson Correlation & 1 & $.772 * *$ & $.814 * *$ & .523 \\
\hline & Sig. (2-tailed) & & .000 & .000 & .022 \\
\hline & $\mathrm{N}$ & 248 & 246 & 248 & 248 \\
\hline \multirow{3}{*}{$\begin{array}{l}\text { Personal } \\
\text { improve } \\
\text { ment o } \\
\text { SMEs } \\
\text { owner }\end{array}$} & Pearson Correlation & $.772 * *$ & 1 & $.780 * *$ & .104 \\
\hline & f Sig. (2-tailed) & .000 & & .000 & .103 \\
\hline & $\mathrm{N}$ & 246 & 248 & 248 & 248 \\
\hline \multicolumn{6}{|l|}{ manager } \\
\hline \multirow{4}{*}{$\begin{array}{l}\text { Livelihoo } \\
\text { d } \\
\text { developm } \\
\text { ent of } \\
\text { local } \\
\text { communi } \\
\text { ty }\end{array}$} & Pearson Correlation & $.814 * *$ & $.780 * *$ & 1 & .772 \\
\hline & Sig. (2-tailed) & .000 & .000 & & .042 \\
\hline & $\mathrm{N}$ & 248 & 248 & 250 & 250 \\
\hline & & & & & \\
\hline \multirow{2}{*}{$\begin{array}{l}\text { Livelihoo } \\
\text { d } \\
\text { developm }\end{array}$} & Pearson Correlation & .523 & .104 & .772 & 1 \\
\hline & Sig. (2-tailed) & .022 & .103 & .042 & \\
\hline $\begin{array}{l}\text { ent in } \\
\text { local area } \\
\text { (Tourism } \\
\text { destinatio } \\
\text { n) }\end{array}$ & $\mathrm{N}$ & 248 & 248 & 250 & 250 \\
\hline
\end{tabular}

From the table we can see that Pearson correlation values of all variable Livelihood development in local area (Tourism destination) is 0.523 due to Small scale tourism related SMEs, that means there is a positive and moderate relationship . The value of sig is 0.022 which is less than 0.05 so it's significant. 
From the table we can see that Pearson correlation values of variable Livelihood development in local area (Tourism destination) is .103 due to Personal improvement of SMEs owner manager which means there is a positive but weak relationship. The value of sig is 0.104 which is less than 0.05 so it's not significant.so if in the area there are Personal improvement of SMEs owner manager it's not factual that owner manager improvement doesn't mean the improvement in local area development.

Pearson value is .772 which there is a positive strong relationship, and sig value is 0.42 which is less than 0.5 significant exist.

\section{Table}

\begin{tabular}{|c|c|c|c|c|}
\hline Model & $\mathrm{R}$ & $\mathrm{R}$ square & $\begin{array}{ll}\begin{array}{l}\text { Adjusted } \\
\text { square }\end{array} & \mathrm{R} \\
\end{array}$ & Std. Error of the Estimate \\
\hline 1 & $\begin{array}{l}.53 \\
8\end{array}$ & .319 & .007 & .599 \\
\hline
\end{tabular}

By testing the value of $\mathrm{R}$ is .538 which mean the relationship between dependent variable and independent variable is moderate, form the value $\mathrm{R}$ square show that there is a change of $31.9 \%$ in Livelihood development in local area (Tourism destination) with respect to variables Small scale tourism related SMEs, Personal improvement of SMEs owner manager and Livelihood development of local community.

\subsubsection{Coefficient}

\begin{tabular}{|c|c|c|c|c|c|c|}
\hline \multirow{3}{*}{\multicolumn{2}{|c|}{ Model }} & \multicolumn{4}{|c|}{ Table } & \multirow{3}{*}{ Sig. } \\
\hline & & \multicolumn{2}{|c|}{$\begin{array}{l}\text { Unstandardized } \\
\text { Coefficients }\end{array}$} & \multirow{2}{*}{$\begin{array}{l}\text { Standardize } \\
\mathrm{d} \\
\text { Coefficients } \\
\text { Beta }\end{array}$} & \multirow[t]{2}{*}{$\mathrm{t}$} & \\
\hline & & B & Std. Error & & & \\
\hline \multirow{4}{*}{1} & $\begin{array}{l}\text { (Constant } \\
\text { ) }\end{array}$ & 3.412 & .227 & & 15.026 & .000 \\
\hline & SM_avg & .158 & .032 & .290 & 4.947 & .000 \\
\hline & PI_avg & .154 & .087 & .194 & 1.775 & .077 \\
\hline & LD_avg & .148 & .042 & .200 & 3.492 & .001 \\
\hline
\end{tabular}

\section{Hypothsis1}

Form the table the sig value for the impact Small scale tourism related SMEs on local area (Tourism destination) is 0.000 which is less than the alpha value of 0.05 . Therefore hypothesis accepted, so the relation significant.

\section{Hypothsis2}

Mention in the table the sig value for the impact of Personal improvement of SMEs owner manager on local area (Tourism destination) is 0.077 which is greater than the alpha value of 0.05 . Therefore hypothesis is rejected.

\section{Hypothsis3}

The sig value for the impact of Livelihood development of local community on local area (Tourism destination) is 0.01 which is less than the alpha value of 0.05 . Therefore hypothesis is accepted.

\section{Limitations of the Study}

There are many causes that deteriorate the quality of the study 
- $\quad$ Some people showed slight attention in the questionnaires and several respondents find difficulty in understanding the content of the questionnaire. We have to respond to those questions which may have led some influence on the perception of these respondents.

- Tourism related Small and Medium Enterprises is an immense topic that most of the people may have no idea about.

- Sometimes people may not intentionally show their true judgment due to some biases.

- There is a chance that all the information which is useful for this research work may not have been completed by the people because of privacy rules, so the results are based on the existing materials only.

- In spite of these limits, a lot of effort was made to ensure that all the data will be obtained through authentic means. We chose samples very carefully that it will signify.

\section{Conclusion and Findings}

After studying the impact of tourism on SMEs and local development, we found that most of people have a sound knowledge about tourism and related SMEs. That was about tourism, in this study there are sub variables to find the tourism impact with respect to tourism related SMEs, personal improvement of SMEs owner manager and livelihood development of local on Livelihood development in local area (Tourism destination). This study elaborate that tourism related SMEs has a positive impact on Livelihood development in local area (Tourism destination).Number of client increased and competition between them increased too. Because of tourism healthy competition between SMEs improved. When we talk about the profit of SMEs it's quite difficult to elaborate. Because most of the respondent felt nervous to talk about that, but from overall discussion we find that tourism increase profit also. Due to the fear of taxes people don't talk about profit. So the administration specialists need to have an appropriate discourse with the nearby region to get their dynamic interest for the tourism advancement exercises additionally they need to enable the area through tourism. Most of the owners are trying to expand their business due to the unexpected increase in tourism. This study talk about impact of SMEs owner manager improvement on Livelihood development in local area (Tourism destination) is quite imaginary. Because improvement of owner manager has nothing to do with locals development or tourism destination development. This research cannot judge the overall condition of community by one or two individuals. This study also says that there is not a significant impact of owner manager improvement on overall society. The effect on the individual improvement of the business people is not so satisfactory. Other point to discuss get-togethers and exercises improves their style of business was evaluated as not satisfactory, that mean not significant. Decision making presentation is considerably more significant in view of the necessities of visitor and neighbourhood towns in Bahawalpur City. They have the chance to go to instructional meetings, workshops, gatherings for improving their businesses. But they are not satisfied enough. Moral of the analysis is that this condition is not satisfactory. In the condition of impact of livelihood of local community on Livelihood development in local area (Tourism destination) .This research explain individually tourism has an impact on the development of local and destination development, their relationship say that they both have a positive relationship. It mean if the people in society is happy and living good life, overall condition of the destination area will be satisfactory. Some of the respondents have been in business for the longest time but are still struggling in their lives and others who are just at the beginning of their venture are seemingly more successful than the ones who have been in business longer than they have been. Question about government assistant, environment issue, community involvement, cultural impact and infrastructure also present there for knowing the other sustainable tourism issues.

\section{Future Recommendation}

- In the future, research will be conducted on why a personal improvement of SMEs don't have a positive effect. Moral of the analysis is that tourism has a positive impact and it will increase the living life of locals and development in tourist area. 
- Research in other areas of South Punjab, Pakistan and international is strongly suggested in light of current events

- Sustainable tourism can be explored in regard to other dimensions such as environmental and socio eco dimension etc.

- Future researchers can use different theories related to their sustainable tourism according to nature of their variables.

\section{Reference}

Beaumont, P. (2013). 5 Definitions of Sustainability - The Green Dandelion.

Commission, T. B. (2005). Sun Microsystems Takes RFID From the Edge to the Enterprise With New Version of Sun Java(TM) System RFID Software. PR Newswire, 1.

Gnanapala, A., \& Sandaruwani, J. A. R. C. (2016). Socio-economic Impacts of Tourism Development and Their Implication on Local Communities. International Journal of Economics and Business Administration, 2(5), 59-67.

Jaafar, M., Rasoolimanesh, S. M., Mohd Bakri, N., \& Rasoolimanesh, \& S. M. (2015). Local Community and Tourism Development: A Study of Rural Mountainous Destinations DEVELOPMENT OF ECOTOURISM PRODUCTS IN KILIM GEOPARK BASED ON TOURIST PERCEPTIONS View project Community Participation in Tourism Development View project Local Community an. Modern Applied Science, 9(8), 407-416. https://doi.org/10.5539/mas.v9n8p407

Mathew, P. V., \& Sreejesh, S. (2017). Impact of responsible tourism on destination sustainability and quality of life of community in tourism destinations. Journal of Hospitality and Tourism Management, 31, 83-89. https://doi.org/10.1016/j.jhtm.2016.10.001

Othman, P., \& Rosli, M. (2011). The impact of tourism on small business performance: Empirical evidence from Malaysian islands. International Journal of Business and Social Science, 2(1), 1121.

Ranasinghe, R. (2014). The Perceived Impacts of Tourism on the Small Scale Entrepreneurs. International Journal of Scientific and Research Publications, 4(10), 1-5.

Sanagustín Fons, M. V., Fierro, J. A. M., \& Patiño, M. G. y. (2011). Rural tourism: A sustainable alternative. Applied Energy, 88(2), 551-557. https://doi.org/10.1016/j.apenergy.2010.08.031

Sutawa, G. K. (2012). Issues on Bali Tourism Development and Community Empowerment to Support Sustainable Tourism Development. Procedia Economics and Finance, 4(Icsmed), 413-422. https://doi.org/10.1016/s2212-5671(12)00356-5

Commission, T. B. (2005). Sun Microsystems Takes RFID From the Edge to the Enterprise With New Version of Sun Java(TM) System RFID Software. PR Newswire, 1.

European Commission. (2017). Annual Report on European SMEs 2016/2017. In SME Performance Review. https://doi.org/10.2873/742338

Jaafar, M., Rasoolimanesh, S. M., Mohd Bakri, N., \& Rasoolimanesh, \& S. M. (2015). Local Community and Tourism Development: A Study of Rural Mountainous Destinations DEVELOPMENT OF ECOTOURISM PRODUCTS IN KILIM GEOPARK BASED ON TOURIST PERCEPTIONS View project Community Participation in Tourism Development View project Local Community an. Modern Applied Science, 9(8), 407-416. https://doi.org/10.5539/mas.v9n8p407

Saayman, M., \& Saayman, A. (2006). Estimating the economic contribution of visitor spending in the Kruger National Park to the regional economy. Journal of Sustainable Tourism, 14(1), 67-81. https://doi.org/10.1080/09669580608668592

World Travel and Tourism Council. (2019). Travel and Tourism: World Economic Impact 2019. 
